\title{
Histological evidence for heterogeneity in the development of preovulatory pig follicles
}

\author{
M. G. Hunter, S. A. Grant and G. R. Foxcroft* \\ A.F.R.C. Research Group on Hormones and Farm Animal Reproduction, University of Nottingham, \\ School of Agriculture, Sutton Bonington, Leics LE12 5RD, UK
}

\begin{abstract}
Summary. Ovaries were collected from naturally cycling gilts during the preovulatory period and the stage relative to the LH surge estimated by measurement of oestradiol and progesterone concentrations in follicular fluid. Many of the follicles recovered had become flaccid with an associated increase in follicular fluid viscosity. Marked infolding of both the granulosa and theca tissue in some follicles suggested early luteinization. However, these morphological changes did not necessarily occur simultaneously in the same follicle, or in all follicles within an ovary. Moreover, they were not consistently related to characteristic differences in the concentration of follicular fluid steroids, suggesting either that the morphological and biochemical aspects of the luteinization of follicles may be independently controlled, or may respond at different rates to the same signal.
\end{abstract}

Keywords: pig; follicle; histology; heterogeneity

\section{Introduction}

Recent studies of pig follicular development have shown considerable morphological and biochemical heterogeneity among ovula tory follicles from the same animal, even during the late follicular phase (Foxcroft \& Hunter, 1985; Foxcroft et al., 1987). However, the study of follicles in the immediate preovulatory period ( $36-40 \mathrm{~h}$ between the $\mathrm{LH}$ surge and ovulation) in the naturally cyclic gilts used in recent studies was complicated by the finding that at this time many follicles had collapsed and become flaccid, the viscosity of the follicular fluid had greatly increased (making it extremely difficult to recover the fluid) and the granulosa cells were difficult to collect and disperse. Preliminary histological studies indicated marked infolding of both granulosa and theca tissue. Although such tissue changes before ovulation were discussed briefly by Hunter (1984) they have not been described in detail for the pig but have been described for carnivores (Brambell, 1956). In the detailed study by Corner (1919) on the origin of the corpus luteum of the sow in which he collected ovaries on the 1st or 2 nd day of oestrus, collapse of the follicle and infolding of the layers were only reported to occur after follicular rupture and release of the ovum.

The purpose of the present study therefore was to investigate in more detail the sequence of morphological changes occurring within and between follicles from pig ovaries recovered at various stages of the preovulatory period.

\section{Materials and Methods}

Animals. Eight (Landrace $\times$ Large White) gilts (approximate body weight $80 \mathrm{~kg}$ ) were checked for oestrus twice daily using a vasectomized boar. The animals were slaughtered and the ovaries recovered on the lst or 2 nd day of detection of 2 nd or 3 rd oestrus (i.e. Day 21 (Day 0 ) or 22 (Day 1) of the oestrous cycle).

*Present address: Department of Animal Science, University of Alberta, Edmonton, Canada T6G 2PS. 

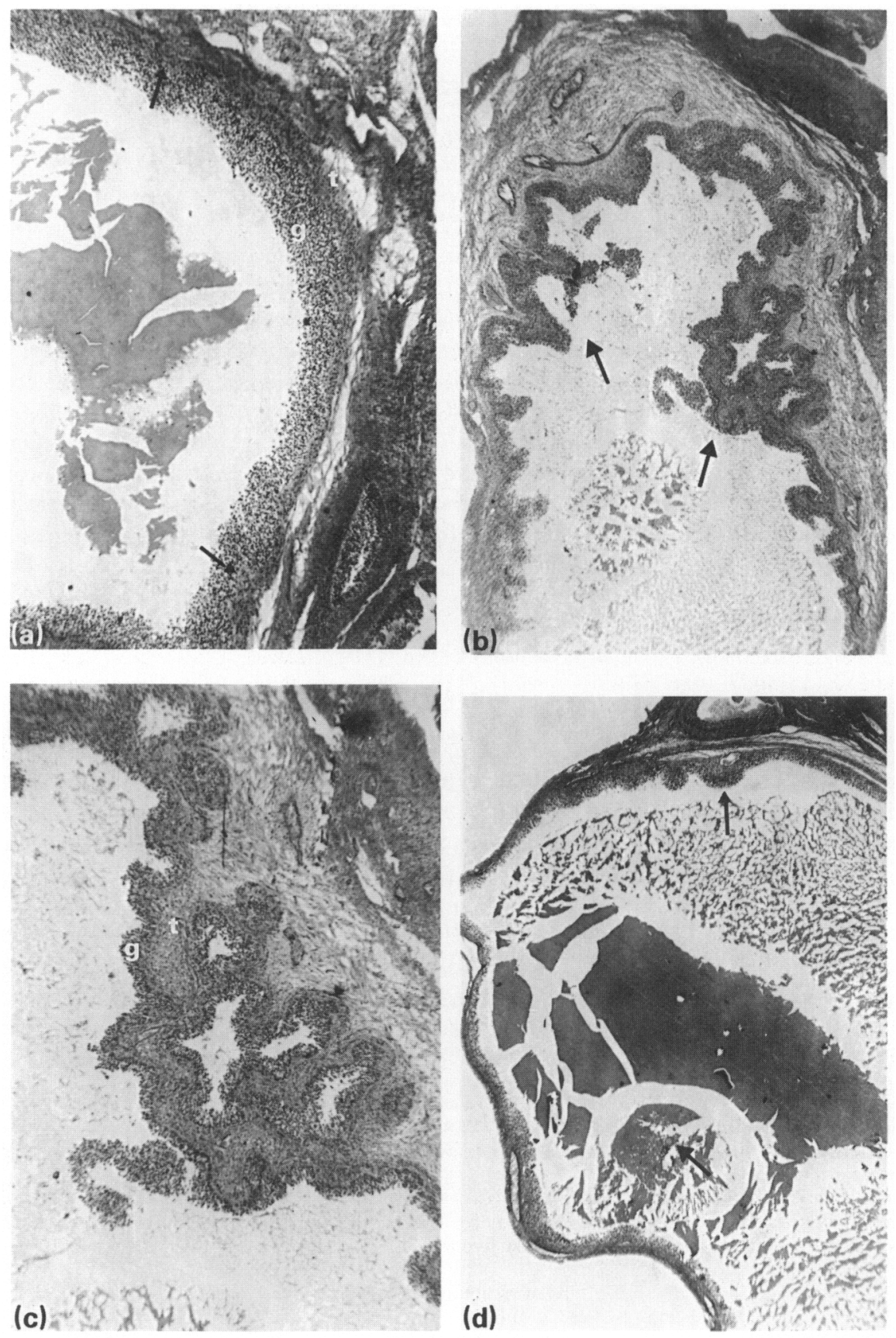

Fig. 1a-d. 


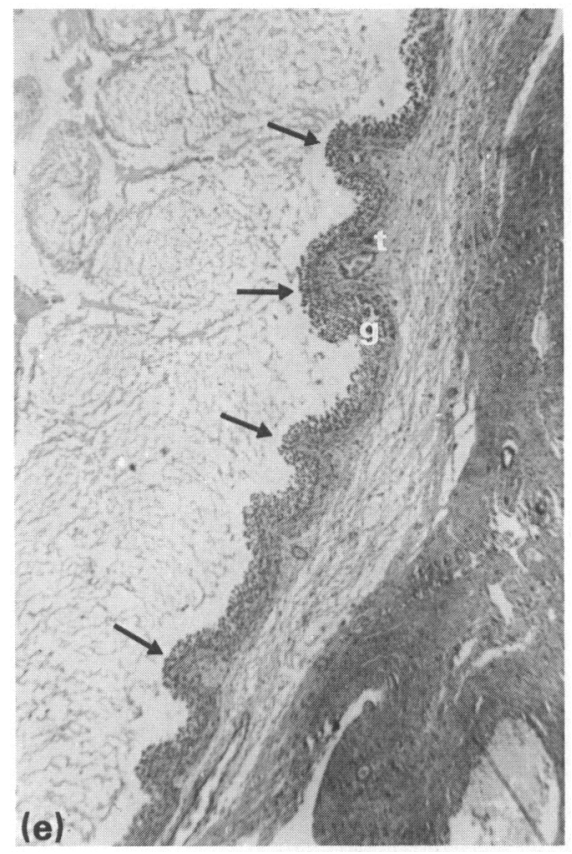

Fig. 1. Sections of pig follicles recovered during the periovulatory period: (a) shows the beginning of the ingrowth of the granulosa $(\mathrm{g})$ and theca $(\mathrm{t})$ layer marked with arrows $(\times 400)$ in a turgid follicle from Gilt 14. Marked infolding of both the granulosa $(\mathrm{g})$ and theca $(\mathrm{t})$ layer in the same flaccid follicle from Gilt 8 is shown in (b) $(\times 200)$ and $(c)(\times 400)$. The oocyte (marked with an arrow) is present in another flaccid follicle from Gilt 8 shown in $(d)(\times 200)$ along with some infolding (also marked with an arrow) which is not associated with the oocyte; (e) shows infolding (marked with arrows) of the granulosa $(\mathrm{g})$ and theca $(\mathrm{t})$ layer in a flaccid follicle from Gilt 13.

Ovarian tissue. Ovaries were collected into chilled phosphate-buffered saline (PBS), pH 7.4, and immediately transferred to the laboratory. The gross morphological appearance of the ovaries was recorded, including the number and size of follicles or corpora lutea. A random selection of the largest follicles from each animal including both flaccid and turgid follicles if present was dissected and placed in Bouin's fixative, and follicular fluid was removed from the remaining follicles with a Hamilton syringe and immediately diluted into $1 \mathrm{ml}$ PBS. The follicles which had been fixed were subsequently embedded in paraffin wax, sectioned at $5 \mu \mathrm{m}$ and then stained using a one-stage M.S.B. (martius-scarlet blue; Drury \& Wallington, 1980) method before examination under the light microscope.

Radioinmunoassays. The concentration of oestradiol in follicular fluid was measured directly without extraction as validated by Grant et al. (1989) according to the method of Foxcroft et al. (1983).

All the samples were measured in one assay in which the limit of sensitivity was $8 \mathrm{pg} / \mathrm{tube}$ and the intra-assay coefficient of variation was $7 \cdot 6 \%$.

The concentration of progesterone in follicular fluid was measured directly without extraction as validated by Grant et al. (1989) according to the method described by Hunter et al. (1986). All the samples were measured in one assay in which the limit of sensitivity was $25 \mathrm{pg} /$ tube and the intra-assay coefficient of variation was $8 \cdot 1 \%$.

\section{Results}

Of the 8 gilts used in this study, 4 were slaughtered just after ovulation and had very recently formed corpora lutea with visible ovulation points. Data from these animals are not described in the present study. The remaining 4 gilts which were slaughtered during the preovulatory period 
were further staged from the physical appearance of the ovaries and in retrospect from the concentrations of oestradiol and progesterone in the follicular fluid. Follicles which had high oestradiol and low progesterone in their follicular fluid were considered to have been recovered before the $\mathrm{LH}$ surge (Gilt 17), and those which had low oestradiol and high progesterone to have been recovered after the peak of the LH surge (Gilts 8, 13 \& 14) (Eiler \& Nalbandov, 1977; Ainsworth et al., 1980; Foxcroft \& Hunter, 1985). The stages of the ovaries recovered from the gilts before ovulation and the characteristics of the follicles from each animal are summarized in Table 1. The ovaries of Gilt 17 had 13 follicles of $8-10 \mathrm{~mm}$ diameter which were recovered before the LH surge and in which the mean oestradiol concentration in the follicular fluid was $478 \mathrm{ng} / \mathrm{ml}$. All the follicles of Gilt 17 were turgid and those examined histologically had a granulosa layer of even thickness with no obvious infolding or increase in viscosity of the follicular fluid. The ovaries from Gilt 14 had 15 large follicles of $7-10 \mathrm{~mm}$ diameter which were recovered after the LH surge and in which the mean oestradiol concentration had declined to $7 \mathrm{ng} / \mathrm{ml}$ and progesterone was increasing. Similar to Gilt 17 , despite the fact that the follicles had been recovered after the surge, they were all turgid with no significant infolding. The beginning of ingrowth of the theca into the granulosa was observed (Fig. 1a) but there was no change in the viscosity of the follicular fluid. However, in Gilt 8, which was also slaughtered after the LH surge, the 15 follicles ranging in diameter from 8 to $11 \mathrm{~mm}$ were a mixture of turgid $(n=8)$ and flaccid $(n=7)$. Infolding and thickening of the granulosa and also infolding of the theca layer were noted in all the turgid and flaccid follicles examined (Figs 1b, c, d). Viscous follicular fluid was recovered from the three flaccid follicles and it may be significant that the one follicle examined which remained turgid and contained fluid of normal viscosity had a lower progesterone concentration $(466 \mathrm{ng} / \mathrm{ml})$ than did the other follicles (mean $=1960 \mathrm{ng} / \mathrm{ml}$ ). Gilt 13, which was also slaughtered after the LH surge, had 12 preovulatory follicles of 7-8 $\mathrm{mm}$ diameter, all of which had collapsed and were flaccid. There were no ovulation points visible on any

Table 1. Stage and characteristics of follicles recovered from 4 gilts during the preovulatory period

\begin{tabular}{|c|c|c|c|c|c|c|}
\hline \multirow[b]{2}{*}{$\begin{array}{l}\text { Gilt } \\
\text { no. }\end{array}$} & \multirow{2}{*}{$\begin{array}{l}\text { Before or } \\
\text { after } \\
\text { LH surge }\end{array}$} & \multirow[b]{2}{*}{$\begin{array}{l}\text { Appearance of } \\
\text { follicles }\end{array}$} & \multirow[b]{2}{*}{$\begin{array}{l}\text { Presence of } \\
\text { infolding }\end{array}$} & \multirow{2}{*}{$\begin{array}{l}\text { Consistency } \\
\text { of follicular } \\
\text { fluid }\end{array}$} & \multicolumn{2}{|c|}{ Follicular fluid conc. } \\
\hline & & & & & $\begin{array}{c}\text { Oestradiol } \\
(\mathrm{ng} / \mathrm{ml})\end{array}$ & $\begin{array}{l}\text { Progesterone } \\
(\mathrm{ng} / \mathrm{ml})\end{array}$ \\
\hline 17 & Before & $\begin{array}{c}\text { All } \\
\text { turgid }\end{array}$ & - & $\begin{array}{l}\text { Normal } \\
\text { Normal } \\
\text { Normal } \\
\text { Normal }\end{array}$ & $\begin{array}{l}541 \\
491 \\
377 \\
503\end{array}$ & $\begin{array}{l}444 \\
420 \\
417 \\
320\end{array}$ \\
\hline 14 & After & $\begin{array}{c}\text { All } \\
\text { turgid }\end{array}$ & - & $\begin{array}{l}\text { Normal } \\
\text { Normal } \\
\text { Normal } \\
\text { Normal } \\
\text { Normal }\end{array}$ & $\begin{array}{l}6 \\
9 \\
7 \\
7 \\
8\end{array}$ & $\begin{array}{r}805 \\
1386 \\
551 \\
597 \\
874\end{array}$ \\
\hline 8 & After & $\begin{array}{l}\text { Turgid/ } \\
\text { flaccid }\end{array}$ & $\begin{array}{l}+ \\
+\end{array}$ & $\begin{array}{l}\text { Viscous } \\
\text { Viscous } \\
\text { Norma! } \\
\text { Viscous }\end{array}$ & $\begin{array}{l}7 \\
5 \\
9 \\
6\end{array}$ & $\begin{array}{r}2178 \\
1633 \\
466 \\
2069\end{array}$ \\
\hline 13 & After & $\begin{array}{c}\text { All } \\
\text { flaccid }\end{array}$ & \pm & $\begin{array}{l}\text { Viscous } \\
\text { Viscous } \\
\text { Viscous } \\
\text { Viscous } \\
\text { Viscous }\end{array}$ & $\begin{array}{r}7 \\
8 \\
9 \\
11 \\
14\end{array}$ & $\begin{array}{l}301 \\
221 \\
161 \\
489 \\
859\end{array}$ \\
\hline
\end{tabular}

The timing of follicle collection relative to the LH surge was based on the appearance of the follicles and their follicular fluid steroid concentrations (see text for details).

Different follicles from the same animal were used for histological investigation or follicular fluid steroid measurement. 
of the follicles. The follicular fluid was viscous in all the follicles investigated, and infolding of the granulosa and theca tissue was observed in 4 (Fig. 1e) of the 7 follicles examined.

\section{Discussion}

The ovaries in this study were all recovered during the periovulatory period, on the 1st or 2nd day after the observation of behavioural oestrus. In the pig, oestradiol concentrations are reported to be maximal some 8-15 h before the peak of the LH surge and the duration of the $\mathrm{LH}$ surge is $\sim 20 \mathrm{~h}$ with ovulation occurring some $40 \mathrm{~h}$ later (Foxcroft \& Van de Wiel, 1982). Based on these criteria and other reports of follicular fluid steroid concentrations during the preovulatory period in the pig (Eiler \& Nalbandov 1977; Ainsworth et al., 1980) it could be accurately predicted that the ovaries from Gilt 17 were recovered before the LH surge, and those from the other gilts recovered after the surge. Although the follicles recovered from Gilts 17 and 14 were similar morphologically, they were different biochemically, particularly in terms of follicular fluid oestradiol concentration which was greatly reduced in Gilt 14. Gilts 8 and 13, like Gilt 14, were slaughtered after the LH surge and so also had very low follicular fluid oestradiol and high progesterone concentrations. However, the follicles of these 3 gilts were all dissimilar morphologically; they possessed either all turgid, all flaccid or a mixture of turgid $(n=8)$ and flaccid ( $n=7)$ follicles, and none, some (4 out of 7) or all of the follicles showed infolding of the granulosa and theca layers. Similarly, there was variation within animals in that infolding was noted in follicles which were both turgid and flaccid, yet not all flaccid follicles showed infolding. Many of the follicles recovered after the LH surge had an increase in viscosity, and a reduction in volume, of the follicular fluid. Such an increase in coagulability of pig follicular fluid before ovulation has also been described by Hunter (1984).

It can clearly be seen from Fig. 1 that the infolding noted in the follicles was due to ingrowth of the theca layer, forcing the granulosa to also form folds. That this infolding is not merely due to the collapse of the follicle is confirmed by the fact that ingrowth was noted in some follicles which were still turgid and had not started to collapse. Furthermore, not all collapsed and flaccid follicles showed signs of infolding.

Corner (1919) described in detail similar collapse and infolding in the follicle but described them as being post-ovulatory events. In the present study, however, although progesterone concentrations had increased in the fluid of many follicles there were no visible ovulation points or signs of rupture in the follicles described (although 4 gilts not described here were slaughtered after ovulation), and in Fig. 1(d) the oocyte is still visible within the follicle. The present results are consistent with observations from a study of the localization of relaxin in pig follicles before ovulation by Bagnell et al. (1987) in which similar ingrowth of the theca into the granulosa layer was found.

Previous studies have demonstrated considerable biochemical heterogeneity among pig ovulatory follicles from the same animal, and the present investigation has also revealed morphological heterogeneity within the ovulatory population. This variation between follicles in terms of morphological and biochemical luteinization in response to the LH surge could be explained by differences in follicular content of both luteinization inhibitor and stimulator (Channing et al., 1982) at the time of the surge, thus resulting in individual responses by the follicles. Indeed several regulatory factors may be anticipated. Firstly, because the morphological changes described in the present study do not necessarily occur simultaneously in the same follicle. Secondly, the differences in morphological development which occurred between follicles from the same ovaries were not related to characteristic differences in the concentration of follicular fluid steroids. Therefore, the morphological and biochemical development of follicles may be independently controlled, or may respond at different rates to the same signal.

We thank the AFRC and MLC for financial support; Vasanthy Tharmananthar and Mr J. Hook for technical assistance; and Dr S. Lynch for the provision of antisera. 


\section{References}

Ainsworth, L., Tsang, B.K., Downey, B.R., Marcus, G.J. \& Armstrong, D.T. (1980) Interrelationships between follicular fluid steroid levels, gonadotropic stimuli and oocyte maturation during preovulatory development of porcine follicles. Biol. Reprod. 23, 621-627.

Bagnell, C.A., Frando, L.B., Downey, B.R., Tsang, B.K. \& Ainsworth, L. (1987) Localization of relaxin in the pig follicle during preovulatory development. Biol. Reprod. 37, 235-240.

Brambell, F.W.R. (1956) Ovarian changes. In Marshall's Physiology of Reproduction, 3rd edn, vol. 1, pp. 397 542 Ed. A. S. Parkes. Longmans, Green \& Co., London.

Channing, C.P., Anderson, L.D., Hoover, D.J., Kolena, J., Osteen, K.G., Pomerantz, S.H. \& Tanabe, K. (1982) The role of non-steroidal regulators in control of oocyte and follicular maturation. Recent Prog. Horm. Res. 38, 331-408.

Corner, G.W. (1919) On the origin of the corpus luteum of the sow from both granulosa and theca interna. Am. J. Anat. 26, 117-183.

Drury, R.A.B. \& Wallington, E.A. (1980) Carleton's Histological Technique, 5th edn, Oxford University Press.

Eiler, H. \& Nalbandov, A.V. (1977) Sex steroids in follicular fluid and blood plasma during the estrous cycle of pigs. Endocrinology 100, 331-338.

Foxcroft, G.R. \& Hunter, M.G. (1985) Basic physiology of follicular maturation in the pig. J. Reprod. Fert., Suppl. 33, 1-19.
Foxcroft, G.R. \& Van de Wiel, D.F.M. (1982) Endocrine control of the oestrous cycle. In Control of Pig Reproduction, pp. 16I-177. Eds D. J. A. Cole \& G. R. Foxcroft. Butterworths, London.

Foxcroft, G.R., Elsaesser, F., Stickney, K., Haynes, N.B. \& Back, H.L. (1983) Ovarian oestrogen-dependent maturation of the luteinizing hormone surge mechanism during prepubertal development in the gilt. $J$. Endocr. 101, 371-380.

Foxcroft, G.R., Shaw, H.J., Hunter, M.G., Booth, P.J. \& Lancaster, R.T. (1987) Relationships between luteinizing hormone, follicle-stimulating hormone and prolactin secretion and ovarian follicular development in the weaned sow. Biol. Reprod. 36, 175-191.

Grant, S.A., Hunter, M.G. \& Foxcroft, G.R. (1989) Morphological and biochemical characteristics during ovarian follicular development in the pig. J. Reprod. Fert. 171-183.

Hunter, M.G., Southee, J.A., McLeod, B.J. \& Haresign, W. (1986) Progesterone pretreatment has a direct effect on GnRH-induced preovulatory follicles to determine their ability to develop into normal corpora lutea in anoestrous ewes. J. Reprod. Fert. 76, 349- 363.

Hunter, R.H.F. (1984) Ovarian follicular development, maturation and atresia in pigs. In La Période Periovulatoire, Colloque de la Société francaise pour l'étude de la Fertilité, pp. 47-54. Masson et Cie, Paris.

Received 3 August 1988 